\section{AUTHOR INDEX \\ VOLUME 39, 1997}

Anderson, R. S. Distribution of Sites and Radiocarbon Dates in the Sierra Nevada: Implications for Paleoecological Prospecting, 121

Baroni, C. see Petri, A., 61

Cherkinsky, A. Obituary - Harold W. Krueger, iv(3)

Cook, G. T. see Scott, E. M., 347

Cordero, R. INGEIS Radiocarbon Laboratory Dates III, 67

Currie, L. A. see Verkouteren, R. M., 269

Donahue, D. see Zhou, W., 19

Eastoe, C. J. The ${ }^{14} \mathrm{C}$ Content of Lithium Metal Used in Benzene Synthesis, 343

Facorellis, Y. Study of the Parameters Affecting the Correlation of Background Versus Cosmic Radiation in $\mathrm{CO}_{2}$ Counters: Reliability of Dating Results, 225

Flessa, K. W. see Goodfriend, G. A., 139

Frischkorn, H. see Santiago, M. F., 49

Genty, D. Bomb ${ }^{14}$ C Recorded in Laminated Spelothems: Calculation of Dead Carbon Proportion, 33

Gillespie, R. Burnt and Unburnt Carbon: Dating Charcoal and Burnt Bone from the Willandra Lakes, Australia, 239

González-Gómez, C. University of Granada Radiocarbon Dates VII, 73; University of Granada Radiocarbon Dates VIII, 299

Goodfriend, G. A. Radiocarbon Reservoir Ages in the Gulf of California: Roles of Upwelling and Flow from the Colorado River, 139

Guida, N. G. see Cordero, R., 67

Harkness, D. D. see Scott, E. M., 347

Higham, T. F. G. Evidence for Late Polynesian Colonization of New Zealand: University of Waikato Radiocarbon Measurements, 149

Hogg, A. G. see Higham, T. F. G., 149

Jull, A. J. T. see Zhou, W., 19, see also Eastoe, C. J., 343

Kawano, E. see Shibata, S., 79

Klinedinst, D. B. see Verkouteren, R. M., 269

Knox, F. B. Least-Squares Fitting a Smooth Curve to Radiocarbon Calibration Data, 193
Kobal, I. see Vokal, B. 285

Koehler, P. A. see Anderson, R. S., 121

Kromer, B. see Levin, I., 205, see also Facorellis, Y., 225

Kronfeld, J. see Vogel, J. C., 27

Leavitt, S. W. Book Review - Nuclear Techniques in Soil-Plant Studies for Sustainable Agriculture and Environmental Preservation, 355

Levin, I. Twenty Years of Atmospheric ${ }^{14} \mathrm{CO}_{2}$ Observations at Schauinsland Station, Germany, 205

Li, K. see Wu, X. H., 293

Liu, Y. F. see Wu, X. H., 293

Long, A. From the Editor, iii(1), iii(2), iii(3), see also Eastoe, C. J., 343

Lu, X. Y. see Wu, X. H., 293

Maniatis, Y. see Facorellis, Y., 225

Massault, M. see Genty, D., 33

Mendes Filho, J. see Santiago, M. F., 49

Nakabayashi, T. see Shibata, S., 79

Nogueira, J. L. see Cordero, R., 67

Perttula, T. K. A Compendium of Radiocarbon and Oxidizable Carbon Ratio Dates from Archaeological Sites in East Texas, with a Discussion of the Age and Dating of Select Components and Phases, 305

Petri, A. Penguin, a Macintosh Application for Entry and Presentation of Radiocarbon-Dated Samples, 61

Punning, J.-M. see Vasil'chuk, Yu., 1

Reesman, R. see Cherkinsky, A., iv(3)

Santiago, M. F. Characterization of Groundwater in the Cariri (Ceara, Brazil) by Environmental Isotopes and Electric Conductivity, 49

Scott, M. Book Review - Bayesian Approach to Interpreting Archaeological Data, 219; Analytical Protocol and Quality Assurance for ${ }^{14} \mathrm{C}$ Analyses: Proposal for a Further Intercomparison, 347

Sewell, D. R. Book Review - Sangre de Cristo: A Novel of Science and Faith, 118

Shibata, S. Research Center of Radioisotopes at University of Osaka Prefecture Radiocarbon Dates I, 79

Silva, C. M. S. V. see Santiago, M. F., 49

Smith, S. J. see Anderson, R. S., 121

Solow, A. R. Estimating Settlement Time, 351 
Taylor, C. B. On the Isotopic Composition of Dissolved Inorganic Carbon in Rivers and Shallow Groundwater: A Diagrammatic Approach to Process Identification and a More Realistic Model of the Open System, 251

Taylor, R. E. Book Review - Relic, Icon or Hoax? Carbon Dating the Turin Shroud, 115

Tucek, C. S. see Eastoe, C. J., 343

Vasil'chuk, A. see Vasil'chuk, Yu., 1

Vasil'chuk, Yu. Radiocarbon Ages of Mammoths in Northern Eurasia: Implications for Population Development and Late Quaternary Environment, 1

Verkouteren, R. M. Iron-Manganese System for Preparation of Radiocarbon AMS Targets: Characterization of Procedural Chemical-Isotopic Blanks and Fractionation, 269

Villafranca-Sánchez, E. see González-Gómez, C., 73, see also González-Gómez, C., 299
Vogel, J. C. Calibration of Radiocarbon Dates for the Late Pleistocene Using U/Th Dates on Stalagmites, 27

Vokal, B. Radiocarbon Releases at the Krsko Nuclear Power Plant, 285

Wang, H. F. see Wu, X. H., 293

Wang, J. J. see Wu, X. H., 293

$\mathrm{Wu}, \mathrm{X}$. H. Histone Adduction With Nicotine: A Bio-AMS Study, 293

Yamada, O. KSU Radiocarbon Dates II, 89

Zhou, W. Radiocarbon AMS Dating of Pollen Concentrated from Eolian Sediments: Implications for Monsoon Climate Change since the Late Quaternary, 19 